\title{
Enabling experimental greenhouse for high-tech application
}

\section{Habilitación de invernadero experimental para aplicación de alta tecnología}

RODRÍGUEZ-FRANCO, Martín Eduardo $\dagger^{1} \dagger^{*}$, MALDONADO-RUELAS, Víctor Arturo ${ }^{1}$, VILLALOBOS-PIÑA, Francisco Javier ${ }^{2}$ and ORTIZ-MEDINA, Raúl Arturo ${ }^{1}$

${ }^{1}$ Universidad Politécnica de Aguascalientes
${ }^{2}$ Instituto Tecnológico de Aguascalientes

ID $1^{\text {st }}$ Author: Martín Eduardo, Rodríguez-Franco / ORC ID: 0000-0002-6804-4777, Researcher ID Thomson: T-15392018, CVU CONACYT ID: 660892

ID $1^{\text {st }}$ Coauthor: Víctor Arturo, Maldonado-Ruelas / ORC ID: 0000-0003-2125-1557, Researcher ID Thomson: I-27742018, CVU CONACYT ID: 209649

ID $2^{\text {nd }}$ Coauthor: Francisco Javier, Villalobos-Piña / ORC ID: 0000-0003-1053-5642

ID $3^{\text {rd }}$ Coauthor: Raúl Arturo, Ortiz-Medina / ORC ID: 0000-0002-3790-3807, Researcher ID Thomson: H-9584-2018, CVU CONACYT ID: 878025

DOI: $10.35429 /$ EJDRC.2021.12.7.9.18

Received March 28, 2021; Accepted June 25, 2021

\begin{abstract}
This work exposes the conditioning of the zenith greenhouse of the Polytechnic University of Aguascalientes for its conformation as a high-tech entity, through the adaptation of sensors, actuators and a controller, which ensure the supervision of the environmental conditions inside, mainly established by the variables of temperature and humidity. The development and application of a computer graphical interface is presented as an intuitive tool for monitoring and controlling the field devices used, and therefore, the environmental conditions provided or recorded from their activation. Likewise, the use of the open communication standard OPC is demonstrated as an alternative for effective interaction between the LabVIEW software, from which the management interface was developed, and the PLC, used as the system controller. The results achieved provide proof of the adequate operation of the devices adapted in the greenhouse installation, the compilation of the information associated with the performance of their task and the manipulation of their operation or reading, from the graphical interface developed for this purpose.
\end{abstract}

High-tech greenhouse, Programmable logic controller, Graphical interface for management

\section{Resumen}

Este trabajo expone el acondicionamiento del invernadero cenital de la Universidad Politécnica de Aguascalientes para su conformación como un ente de alta tecnología, a través de la adaptación de sensores, actuadores y un controlador, que aseguren la supervisión de las condiciones ambientales al interior, principalmente establecidas por las variables de temperatura y humedad. Se presenta el desarrollo y la aplicación de una interfaz gráfica por computadora como una herramienta intuitiva para el monitoreo y control de los dispositivos de campo empleados, y por ende, de las condiciones de entorno aportadas o registradas a partir de su activación. Asimismo, se demuestra el uso del estándar de comunicación abierta OPC, como una alternativa para la interacción efectiva entre el software LabVIEW, a partir del cual fue desarrollada la interfaz para gestión, y el PLC, utilizado como controlador del sistema. Los resultados alcanzados brindan constancia de la adecuada operación de los dispositivos adaptados en la instalación del invernadero, la recopilación de la información asociada al desempeño de su tarea y la manipulación de su operación o lectura, desde la interfaz gráfica desarrollada para tal fin.

Invernadero de alta tecnología, Controlador lógico programable, Interfaz gráfica para gestión

Citation: RODRÍGUEZ-FRANCO, Martín Eduardo, MALDONADO-RUELAS, Víctor Arturo, VILLALOBOS-PIÑA, Francisco Javier and ORTIZ-MEDINA, Raúl Arturo. Enabling experimental greenhouse for high-tech application. ECORFAN Journal-Democratic Republic of Congo. 2021, 7-12: 9-18

\footnotetext{
* Correspondence to Author (e-mail: mc190002@alumnos.upa.edu.mx)

$\dagger$ Researcher contributing first author.
} 


\section{Introduction}

The state of Aguascalientes is characterized by having a temperate semi-dry climate in about $80 \%$ of its territory, with a dominance of semiarid soil (De la Cerda Lémus, 2011); Despite this, agriculture constitutes one of the main economic activities in the state, to which around $14 \%$ of its surface is allocated (CPLAP, 2019). The most widely used cultivation system is temporary, with $84 \%$ of the territory occupied; which portrays the climatic dependence of agricultural practice in the state, which together with the scarce sources of financing and the lack of technological application, have limited the evolution of the production and commercialization of the crops obtained (Borja Bravo, Rodríguez Licea, Osuna Ceja, \& López Aguilar, 2016).

The practice of protected agriculture, from the introduction of greenhouses, has recently been adopted by producers of the entity; with a rapid acceptance and expansion, from 87.1 hectares destined in 2013 to 102.8 hectares in 2015 (SIAP, 2015). Currently, this option of cultivation is present in all the municipalities of the state, being Pabellón de Arteaga, Calvillo and San Francisco de los Romo those that concentrate about $50 \%$ of the total production, consisting mainly of red tomato, seedling and strawberry (SIAP, 2014).

Therefore, this agricultural scheme raises the need to diversify the production of vegetables, in search of promoting technological development that allows efficient cultivation systems, in order to guarantee greater production and quality (Borja Bravo, Rodríguez Licea, Osuna Ceja , \& López Aguilar, 2016).

Thus, the preservation of environmental conditions inside a greenhouse is essential for the proper development of the crops produced under this scheme (Çayli, 2020). A large number of variables determine the growth of the plant in the confined space, however, those with greater dominance are usually associated with the surrounding climate (Ghani, et al., 2019), established mainly by temperature (Baglivo, et al., 2020). ) and humidity (Amani, Foroushani, Sultan, \& Bahrami, 2020).
Thus, the adaptation of technological means and devices that allow the monitoring and regulation of the magnitude acquired by such variables, will promote their establishment at optimal values, depending on the type of crop that is owned or desired to be produced (Iddio, Wang, Thomas, McMorrow, \& Denzer, 2020).

\section{Background}

The Polytechnic University of Aguascalientes has two greenhouses located east of Building 4; of these, the exposed intervention was applied in the greenhouse with the largest dimension, which is of the zenith type (figure 1). It is worth mentioning that the physical installation of this greenhouse had to be rehabilitated in its entirety, since it was in disuse. And, since the conditions of the deterioration suffered during a considerable period without functionality were highly evident, it was necessary to cover the structure with plastic, as well as the placement of actuators to perform the functions of heating, air recirculation and operation of the Windows.

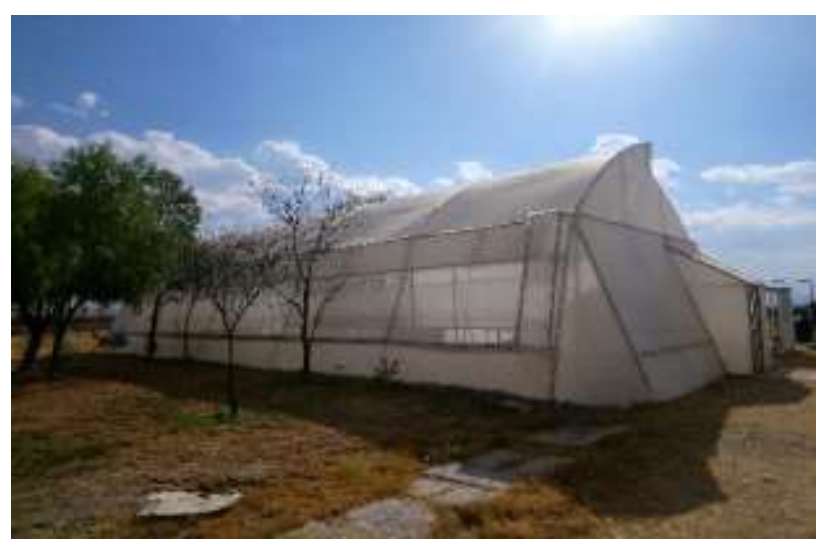

Figure 1 Zenith greenhouse of the Polytechnic University of Aguascalientes

Source: Own Elaboration, 2021

Inside the greenhouse, on most of the isolated soil, some furrows were formed, as can be seen in Figure 2. Such alignments will allow the sowing and cultivation of different plant species, whose physiological properties are ideal for the tasks to be carried out in the Research Laboratory of the university itself, on which this facility depends, in its orientation towards agricultural experimentation. Thus, in order to facilitate the movement and maneuvering of people inside the greenhouse, as a support for the preservation of its function, a corridor was enabled that crosses the confined space throughout; which was later properly constituted with cement. 


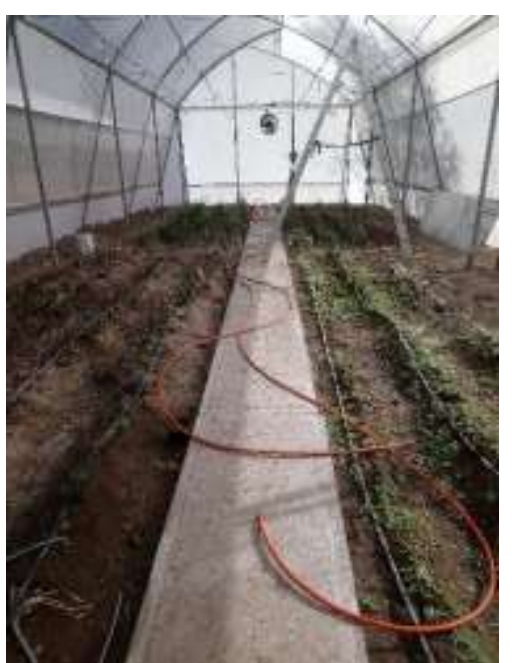

Figure 2 Interior of the zenith greenhouse Source: Own Elaboration, 2021

The proposed organization of the surface for cultivation in four quadrants and, of these, in two areas (Figure 3), favored the distribution of the devices used to cover the entire installation; in addition, it will contribute to the establishment of a certain space for the sowing of a particular species, once in operation. Likewise, the electrical wiring was adapted, in proximity to the side walls of the greenhouse, to provide an electrical supply to the field devices that require it, or to guide the information coming from them to a concentrator. There was also a tank for storage and supply of water to the irrigation system, as well as a pressurizer, for dispersing and applying it, in the form of steam, to the crops, to complete the rehabilitated agricultural facility.

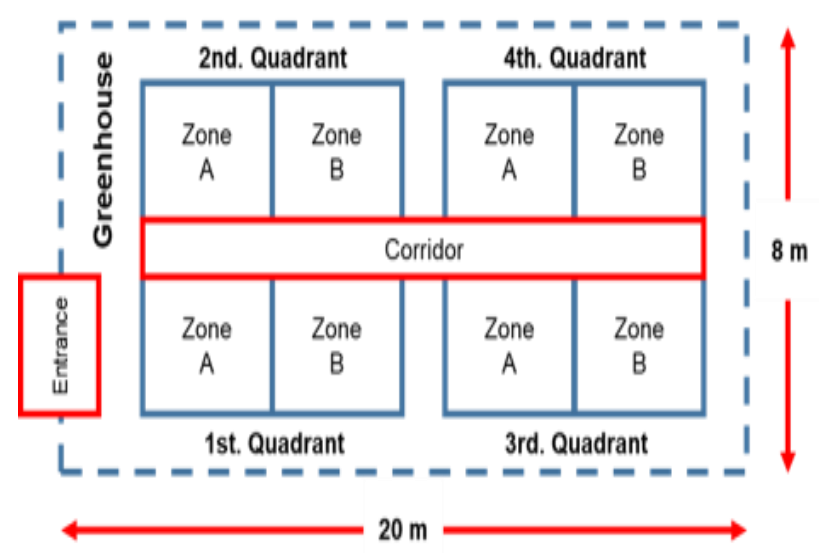

Figure 3 Organization of the space inside the greenhouse Source: Own Elaboration, 2021

It was a priority of the present study to combine the functionality of all the field devices adapted to the interior of the greenhouse, after its habilitation; through the configuration of a central controller within the installation itself.
Such a controller establishes communication with a graphical computer interface, developed for the management of the components and equipment used in the confined space; which is executed from a nearby location, through serial communication. It is worth highlighting the delimitation in the preservation of the environmental conditions inside the greenhouse, from the exclusive effect of the temperature and humidity variables; which tend to have greater dominance in the environment surrounding the crop, determining its optimal growth (Shamshiri, et al., 2018).

\section{Installation of actuation devices}

After fitting out the greenhouse, we proceeded to install the devices that would affect any change in the confined environment; which leads to the preservation of specific conditions for the proper development of the crops to be introduced. Although, there was an environment isolated from the outside climate, whose internal effect could be regulated by the manual opening or closing of the windows, which led it to be categorized as a low-tech greenhouse, it was necessary to adapt devices that allowed to reach a level of medium or high technology; in accordance with the objectives set for this intervention.

Under the proposed technological variation scheme, the need to install elements for the coordinated regulation of the main environmental factors inside the greenhouse was determined. Therefore, when these conditions are established, especially due to the variables of temperature and humidity, it was necessary to consider components that allow a homogeneous thermal distribution throughout the confined space, supply water to the crops or inject the appropriate dose of steam to the environment.

This while providing feedback to the user on the condition reached. It is worth mentioning the use of the drip irrigation technique to make the use of water more efficient, by directing it effectively towards the root of the plant. The elements considered for the defined performance functions are listed in table 1 . 


\begin{tabular}{|l|l|}
\hline Quantity & \multicolumn{1}{|c|}{ Device } \\
\hline 1 & System energized indicator light. \\
\hline 1 & System stopped indicator light. \\
\hline 1 & System in operation indicator light. \\
\hline 4 & $\begin{array}{l}\text { Solenoid valve for activation of the irrigation } \\
\text { system. }\end{array}$ \\
\hline 1 & $\begin{array}{l}\text { Set of nebulizers for humidity regulation in } \\
\text { the environment. }\end{array}$ \\
\hline 4 & Motor relays for driving the side windows. \\
\hline 1 & Heater. \\
\hline 1 & Air recirculator. \\
\hline 1 & $\begin{array}{l}\text { Pump for filling supply tank for irrigation } \\
\text { system. }\end{array}$ \\
\hline
\end{tabular}

Table 1 Actuation devices

Source: Own Elaboration, 2021

For activation and management of the aforementioned devices, the electrical panel of Figure 4 was adapted, in which the necessary connections converge to achieve such functions. However, since the operation of each actuator was originally carried out separately, a different actuation, usually manual, was available to enable each one; which highlighted the lack of coordination between the multiple elements, for the joint management of the environmental conditions inside the greenhouse. Only for the irrigation system was there a timer that can govern its operation based on schedules and time periods established by the user.

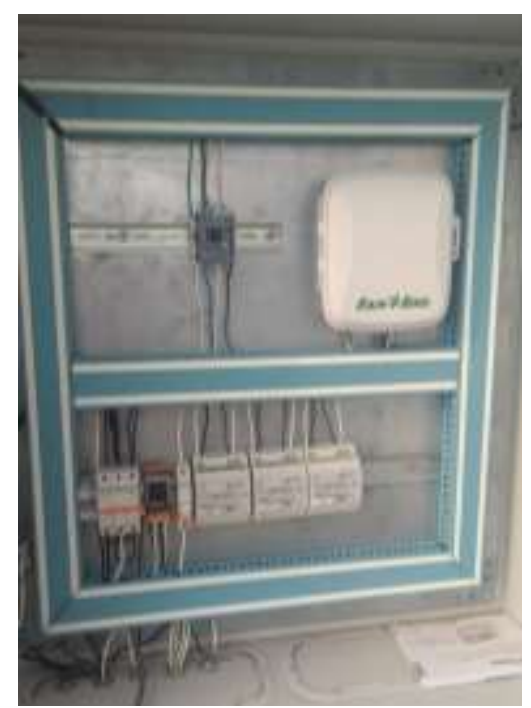

Figure 4 Control panel interior Source: Own Elaboration, 2021

\section{Adaptation of the perception system}

From a perception system, the provision of information related to the status of the control elements and the condition of the environment inside the greenhouse, encourages the decisionmaking process on the parameters that need to be modified to achieve an environment that contributes to the development of crops. Therefore, from the data collected from the confined environment, it is possible that the contemplation of the actions to be carried out may be left to an operator, or it may be carried out automatically by the system controller itself, as considered. .

Because the functionality of the greenhouse will largely depend on the magnitudes of temperature and humidity registered indoors, the need to identify the index of the first variable in the environment surrounding the crops is established; while the second variable can be measured both in the environment and in the soil, in proximity to the root of the plant. Likewise, other elements are considered that allow the activation or suspension of the central control task, the activation of the side windows of the greenhouse and the verification of the water content in the tank that supplies the irrigation system. The devices considered for the recording of the described signals are shown in Table 2.

\begin{tabular}{|l|l|} 
Quantity & \multicolumn{1}{c|}{ Device } \\
\hline 4 & $\begin{array}{l}\text { Analog sensor of temperature and humidity } \\
\text { in the environment surrounding the plant. }\end{array}$ \\
\hline 8 & $\begin{array}{l}\text { Analog soil moisture sensor close to the } \\
\text { root of the plant. }\end{array}$ \\
\hline 1 & System stop button \\
\hline 1 & System start button \\
\hline 1 & Selector for activating side windows \\
\hline & $\begin{array}{l}\text { Water level sensor in the tank to supply the } \\
\text { irrigation system. }\end{array}$ \\
\hline
\end{tabular}

Table 2 Perception devices

Source: Own Elaboration, 2021

\section{Process controller integration}

Once the devices for recording information related to the condition of the process had been contemplated, as well as those that affect the change in its present operating state, a controller was selected that would concentrate the action of both types of elements, to automate greenhouse function. 
Being possible to develop a proposal that promotes the application of a variety of devices, but ensuring that their functionality is not compromised by exposure to an environment of high humidity and prone to corrosion or electric shock; so the use of a programmable logic controller (PLC) is chosen as the brain of the process.

An Allen Bradley brand Micrologix 1500 PLC (Figure 5), has been considered as manager for the automation of the greenhouse; it is a device with 12 digital inputs and 12 digital outputs. The inputs can be configured to sink or source, depending on the type of sensor or element used, while the outputs are to relay, which does not condition the use of any particular magnitude or type of electrical supply; which will depend on each device to connect. Communication with the PLC, for its programming, management or data exchange, is possible through the use of two serial ports, mindin and DB9, arranged. While the use of expandable modules extends the functionality of the PLC, by adding a greater number of analog or digital inputs and outputs, as needed.

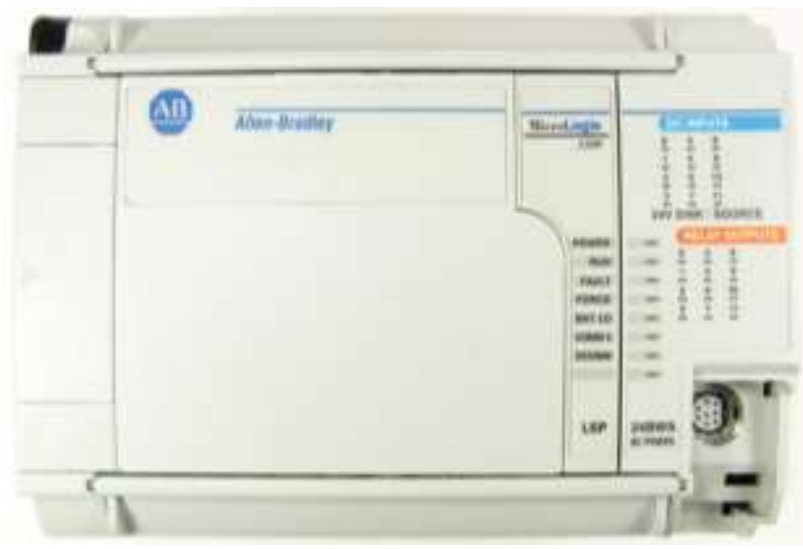

Figure 5 PLC Micrologix 1500 Allen Bradley Source: www.rockwellautomation.com, 2021

In this case, the adaptation to the PLC of different 1769-IF4XOF2 expansion modules, also of the Allen Bradley brand, was required; This module is shown in Figure 6. The function of this device is the interpretation of the information coming from the temperature and humidity sensors arranged inside the greenhouse, whose signal emitted is analog. In total there are 12 entries of this type, divided into three required modules.
Each module is equipped with four inputs with a reading range, in voltage from 0 to $10 \mathrm{~V}$ and in current from 0 to $20 \mathrm{~mA}$, and two analog outputs from 0 to $10 \mathrm{~V}$; at 16-bit signed resolution in both cases. It is worth mentioning that no analog output was used in this application.

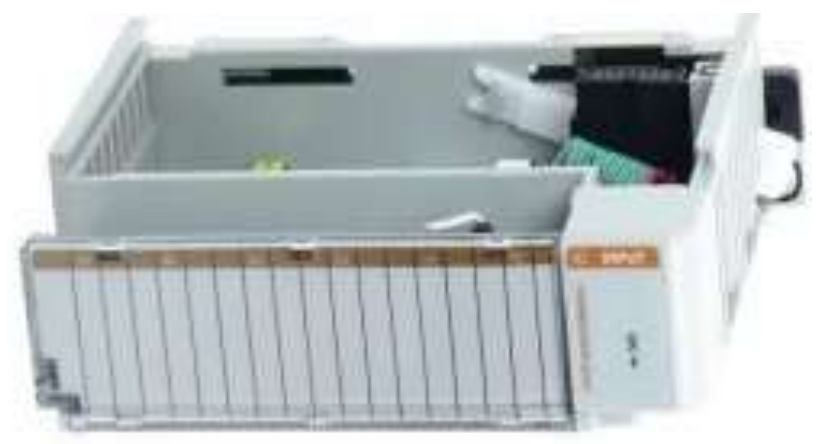

Figure 6 1769-IF4XOF2 Analog Input Module Source: www.rockwellautomation.com, 2021

With regard to the action units to be managed, which are exclusively digital, a total of 15 outputs are counted to be used; between devices for the preservation of the temperature and humidity conditions inside the greenhouse, as well as for the indication of the state of the process. However, considering that the proposed PLC only has 12 available spaces, it was necessary to consider the use of a 1769OW16 expansion module, also from the Allen Bradley brand, for the connection of the remaining elements. This module, shown in Figure 7, has 16 relay outputs; for which, as with the PLC outputs, the connection of loads in alternating current or direct current will be indistinct.

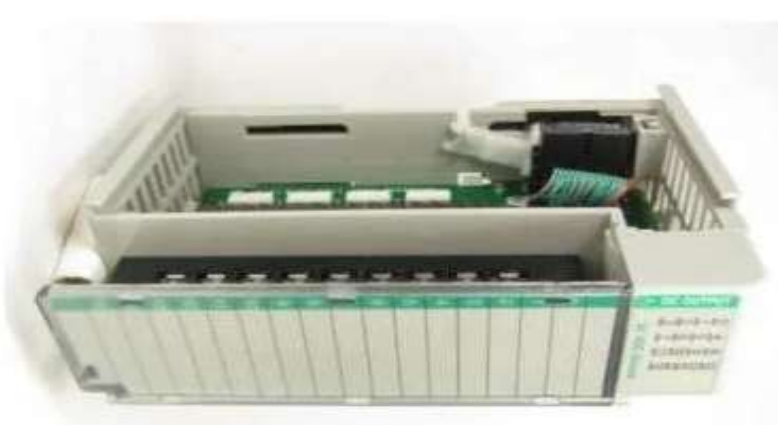

Figure 7 1769-OW16 Digital Output Module Source: www.rockwellautomation.com, 2021 
Having established the modules that will house the physical inputs and outputs in addition to those available in the PLC to be used, it is proposed to organize them in tables 3 and 4 , respectively.

In such tables, in addition to presenting the number of devices related to a particular function, they are assigned a specific address, either of the PLC or of the module, to which they will be connected to fulfill the corresponding reading or writing task. It is worth mentioning the indication of the location, inside the greenhouse, of each of the sensors or actuators used, based on the sectioning previously proposed in Figure 3.

\begin{tabular}{|c|c|c|}
\hline Quantity & Device & Address \\
\hline 4 & $\begin{array}{l}\text { Analog sensor of } \\
\text { temperature and humidity in } \\
\text { the environment } \\
\text { surrounding the plant. }\end{array}$ & $\begin{array}{l}\text { I:1.0 (quadrant } \\
1 \text { ) } \\
\mathrm{I}: 1.1 \text { (quadrant } \\
2 \text { ) } \\
\mathrm{I}: 1.2 \text { (quadrant } \\
3 \text { ) } \\
\mathrm{I}: 1.3 \text { (quadrant } \\
4 \text { ) }\end{array}$ \\
\hline 8 & $\begin{array}{l}\text { Analog soil moisture sensor } \\
\text { close to the root of the } \\
\text { plant. }\end{array}$ & $\begin{array}{l}\text { I:2.0 (quadrant } \\
1, \text { section A) } \\
\text { I:2.1 (quadrant } \\
1, \text { section B) } \\
\text { I:2.2 (quadrant } \\
2 \text {, section A) } \\
\text { I:2.3 (quadrant } \\
2 \text {, section B) } \\
\text { I:3.0 (quadrant } \\
3, \text { section A) } \\
\text { I:3.1 } \\
\text { (quadrant3, } \\
\text { section B) } \\
\text { I:3.2 (quadrant } \\
4, \text { section A) } \\
\text { I:3.3 (quadrant } \\
4, \text { section B) }\end{array}$ \\
\hline 1 & System stop button. & $\mathrm{I}: 0 / 0$ \\
\hline 1 & System start button. & $\mathrm{I}: 0 / 1$ \\
\hline 1 & $\begin{array}{l}\text { Selector for activating side } \\
\text { windows. }\end{array}$ & $\mathrm{I}: 0 / 2$ \\
\hline 1 & $\begin{array}{l}\text { Water level sensor in the } \\
\text { tank for the irrigation } \\
\text { system. }\end{array}$ & $\mathrm{I}: 0 / 3$ \\
\hline
\end{tabular}

Table 3 Description of inputs for the PLC Source: Own Elaboration, 2021

\begin{tabular}{|c|c|c|}
\hline Quantity & Device & Address \\
\hline 1 & $\begin{array}{l}\text { System energized indicator } \\
\text { light. }\end{array}$ & O:0/0 \\
\hline 1 & $\begin{array}{l}\text { System stopped indicator } \\
\text { light. }\end{array}$ & O:0/1 \\
\hline 1 & $\begin{array}{l}\text { System in operation } \\
\text { indicator light. }\end{array}$ & $\mathrm{O}: 0 / 2$ \\
\hline 4 & $\begin{array}{l}\text { Solenoid valves for } \\
\text { activation of the irrigation } \\
\text { system. }\end{array}$ & $\begin{array}{l}\text { O:0/3 (quadrant } \\
\text { 1) } \\
\text { O:0/4 (quadrant } \\
\text { 2) } \\
\text { O:0/5 (quadrant } \\
\text { 3) } \\
\text { O:0/6 (quadrant } \\
\text { 4) }\end{array}$ \\
\hline 1 & $\begin{array}{l}\text { Nebulizers for humidity } \\
\text { regulation in } \\
\text { environment. }\end{array}$ & O:0/7 \\
\hline 4 & $\begin{array}{l}\text { Motor relays for driving } \\
\text { the side windows. }\end{array}$ & $\begin{array}{l}\text { O:0/8 (window } \\
\text { opening 1) } \\
\text { O:0/9 (window } \\
\text { closure 1) } \\
\text { O:0/10 } \\
\text { (window } \\
\text { opening 2) } \\
\text { O:0/11 } \\
\text { (window } \\
\text { closure 2) }\end{array}$ \\
\hline 1 & Heater. & $\mathrm{O}: 1 / 0$ \\
\hline 1 & Air recirculator. & $\mathrm{O}: 1 / 1$ \\
\hline 1 & $\begin{array}{l}\text { Pump for filling supply } \\
\text { tank for irrigation system. }\end{array}$ & $\mathrm{O}: 1 / 2$ \\
\hline
\end{tabular}

Table 4 Description of outputs for the PLC Source: Own Elaboration, 2021

\section{Description of outputs for the PLC Source: Own elaboration, 2021}

Since this implementation covers the validation of the operation of the greenhouse intervened as a high-tech entity, the communication system for managing it from a computer was provisional. This determination was made in consideration of the fact that, given the environmental conditions that will prevail inside the greenhouse, once it is in operation, it is not advisable to manage its condition from inside the installation itself, proposing the adaptation of some means that enables timely supervision of the variables to be analyzed and the devices used, remotely. This mode of management enables the continuity of this work.

In this case, the tests for the operation of the greenhouse were developed from the access section, in which the environmental conditions are isolated from those present in the main space using a second door. 
In addition, if the functionality of the controller is validated from the data acquired from the sensors, the emission of the respective signals to the actuators; as well as in the performance of the tasks of sending and receiving data from it to the computer used. It is worth mentioning that for the tests carried out, it was not necessary to invest a considerable time that implied a prolonged exposure of the computer equipment to the conditions even in the isolated space.

Communication between the PLC and the computer was established through a 1761CBL-PM02 serial cable in conjunction with a RS232-USB serial adapter. For its part, an application developed from a virtual instrument in LabVIEW software manages the variables of interest within the greenhouse; this through the presentation of the data acquired by the sensors and the possibility of entering the values destined for the actuators. Therefore, the interaction between PLC and computer is completed through the use of an OPC (OLE for process control) utility. Figure 8 shows the relationship between the elements of the communication system developed.

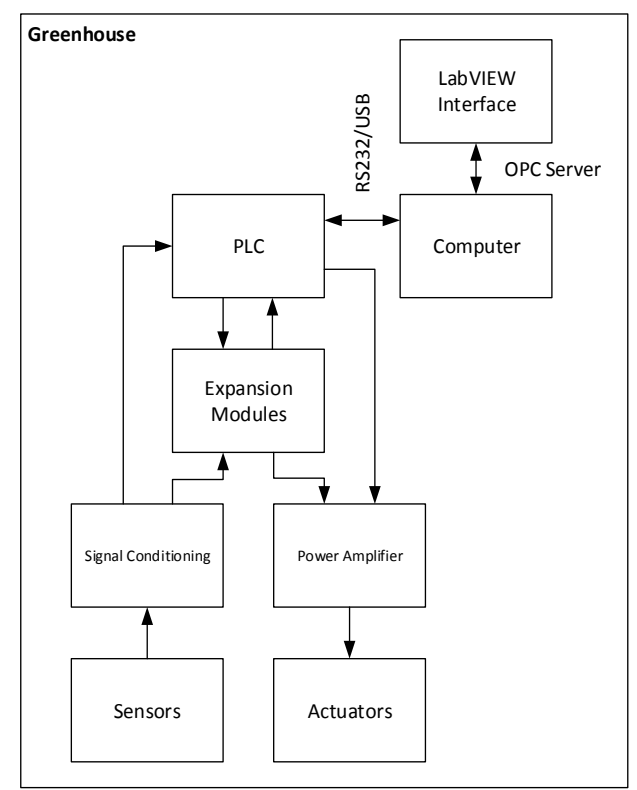

Figure 8 Interaction between components of the communication system

Source: Own Elaboration, 2021

OPC is an open standard for the interconnection of applications based on the Windows operating system and process control hardware, such as a PLC (Rodríguez Penín, 2013).
Thus, the use of OPC allows access to the registers of the variables stored in the memory of a PLC, and allocate such information to a software application executed on a computer or; failing that, it is also possible to modify the data present in said registers, and the reassignment of information by means of the software application used. The realization of both functions is possible through a specific link software utility.

In this case, the own LabVIEW OPC Server was used for the direct exchange of information with the PLC, performing both the reading of the data provided by each sensor inside the greenhouse, as well as the writing of those that are intended for each actuator used. . Thus, the virtual instrument developed in LabVIEW for managing the functionality of the greenhouse was divided according to the signals acquired or emitted, as the case may be, into: side windows, irrigation system, heat and humidity exchange, tank level, system status, ambient temperature and humidity, and soil moisture, as shown in Figure 9.

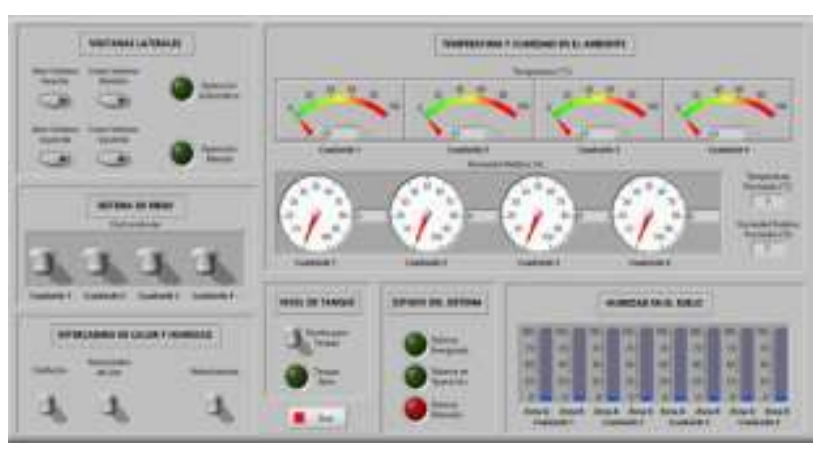

Figure 9 LabVIEW interface for managing environmental variables and devices inside the greenhouse

Source: Own Elaboration, 2021

The developed interface was divided into seven sections. In the upper right portion are located the buttons that allow the activation of the side windows of the greenhouse, in case it is decided to manipulate them manually, by choosing such a configuration from the selector provided. Likewise, the signaling elements corresponding to the mode of operation are located: manual or automatic. Below are the controls that activate the irrigation system for each quadrant, as required. While, in the lower right portion there are the buttons for the action of the heater, the recirculator and the nebulizers. 
On the other hand, in the upper left section of the interface, the indicators of the variables of temperature and humidity in the environment are shown, arranged in each quadrant of the greenhouse, which are represented in degrees Celsius and in percentage, respectively. The measurement of humidity in the soil, corresponding to each zone, is displayed in the lower left portion, whose representation is also in percentage. Likewise, in the lower middle section of the interface, the indicators referring to the operation of the system are located: energized, in operation or stopped; as the element for the activation of the tank filling and its respective indicator.

\section{Field device operation}

The validation of the proper functioning of the system for managing the environmental conditions inside the greenhouse was carried out gradually. In this way, it began by verifying the signals associated with the variables of interest directly in the devices from which they came, or towards those to which they were destined, as the case may be. Thus, it was observed that the digital type sensors used, such as the buttons, the selector and the water level sensor in the tank, emitted a change in their operating state when they were activated. Thus, as if it conserved such signal during the time that they were intervened; yielding satisfactory results.

Regarding analog type sensors, specifically temperature and humidity in the environment, it was validated that these could describe a variable behavior within the ranges of 15 to $35^{\circ} \mathrm{C}$, for temperature, and 50 to $85 \%$ relative humidity. Said variation of conditions was induced by the activation of the nebulizers, for the progressive humification of the place where the reading was taken, this in the case of relative humidity, while the heater and the air recirculator were used to affect the temperature.

Such actions also made it possible to verify the correct operation of the actuators on which the homogenization of temperature and humidity inside the greenhouse will depend, once in operation; and that, however, for now, they were operated manually.
The behavior of humidity in the soil could only be identified by activating the irrigation system, by the action of the solenoid valves that establish its operation; Through which, the soil surrounding the sensor could be moistened, also progressively, and the associated signal appreciated. Regarding the pump that supplies water to the tank, its operation was also corroborated from the water level captured by the sensor arranged for this purpose, being able to characterize its activation, once the sensor stops detecting the liquid at the height at which it has been placed inside the tank, to preserve its filling.

Likewise, the proper operation of the side windows was confirmed, through the use of the selector provided, in manual mode, and the direct energization of the gearmotors that led to the opening or closing of each of these, as required, allowing the indistinct modification between both actions. Finally, the activation of the lamps used to signal the status of the system was validated, once constituted, for the management of the greenhouse.

\section{Controller operation and management interface}

After characterizing the expected response in both the sensors and the actuators used, even manually, they continued to be connected to the input and output terminals of both the PLC and the built-in expansion modules. Validating that the union between the conductors and terminals of the PLC was adequate, prior to its energization. To later carry out a reading test of all the sensors used, inducing a variation in the operating state of each one, regardless of its type, from the activation of the actuators, just as it was done during the performance of the previous tests, only in this case, combining the function of both types of devices from the loaded program to the PLC.

Thus, the modification of the values acquired from the sensors, in addition to the manipulation of the actuators from the PLC's own programming, managed from the respective computer software, made it possible to ensure the required behavior in these. Therefore, the assembly of the graphical interface for the manipulation of the PLC registers, where the values that represent the data derived from the reading and writing of the field devices are stored, as the case may be, was ensured without complications.

RODRÍGUEZ-FRANCO, Martín Eduardo, MALDONADO-RUELAS, Víctor Arturo, VILLALOBOS-PIÑA, Francisco Javier and ORTIZMEDINA, Raúl Arturo. Enabling experimental greenhouse for hightech application. ECORFAN Journal-Democratic Republic of Congo. 2021 
Thus, from the LabVIEW interface it was possible to know the values read by each sensor used, in addition to manipulating the arranged actuators; with which, the variation in the operation of the latter favored the change in the readings made.

\section{Conclusions}

The intervention described allows to have a fully rehabilitated greenhouse, and installed electrical, electronic and electromechanical devices and equipment inside, which will enable it to be used in small-scale cultivation or experimentation tasks. Although the regulation of the environmental conditions inside said space is still carried out in an open loop, by the action of an operator from the developed graphical interface, the installation that is now available will allow the incorporation, in the short term, of strategies for the automatic control of the implicit temperature and humidity variables. Such assertion is based on the fact of having sensors, actuators and a controller in continuous interaction with the environment confined in the greenhouse and with each other, the corroboration of its adequate operation and the concentration of the data exchanged within the PLC used as controller.

The full identification of the type of signals coming from the sensors, as well as those that would be emitted to the actuators, led to the adequate organization of the input and output terminals required in the PLC. On the other hand, the adaptation of the expansion modules contemplated, both for analog inputs and digital outputs, allowed the provision of additional terminals to those originally established in the PLC, for the connection of all the devices used. Thus, the use of expansion modules assumed the connection of analog sensors, for the management of this type of reading, in addition to the connection of other digital actuation devices that could not be directly connected to the PLC due to lack of terminals.

On the other hand, the adaptation of the graphical computer interface, for the management of the functions of the devices inside the greenhouse, has promoted a fast, intuitive and comfortable way to interact with such elements, for the modification or recording of the conditions. associated environmental conditions.
The communication between the LabVIEW virtual instrument, the basis of the management interface, and the PLC, based on the use of the open OPC standard, has been very useful for the success of this application; so that it was not necessary to use any other device, connection or communication protocol for the exchange of data between both elements; which, without a doubt, sped up the validation process performed.

Thus, the aspects described give proof of the qualification and conditioning of the zenith experimental greenhouse of the Polytechnic University of Aguascalientes, for its operation as a high technology system; with the objective of completing this technological scheme in the short term, from the closure of the control loop or feedback in it. Such purpose provides the necessary motivation to give continuity to the work developed up to this point. It should be noted that, since its establishment, the greenhouse has been gradually used in the cultivation of plants for the extraction of essences, for which, for now, it is expected to solve the demand necessary for this purpose..

\section{References}

Amani, M., Foroushani, S., Sultan, M., \& Bahrami, M. (2020). Comprehensive review on dehumidification strategies for agricultural greenhouse applications. Applied Thermal Engineering, 115979.

Baglivo, C., Mazzeo, D., Panico, S., Bonuso, S., Matera, N., Congedo, P. M., \& Oliveti, G. (2020). Complete greenhouse dynamic simulation tool to assess the crop thermal wellbeing and energy needs. Applied Thermal Engineering, 115698.

Borja Bravo, M., Rodríguez Licea, G., Osuna Ceja, E. S., \& López Aguilar, L. (2016). Importancia económica y competitividad de las cadenas agropecuarias en Aguascalientes, México. Investigación y Ciencia, 5-12.

Çaylı, A. (2020). Temperature and relative humidity spatial variability: An assessment of the environmental conditions inside greenhouses. Fresenius Environmental Bulletin, 4954-4962. 
CPLAP, C. G. (Septiembre de 2019). Datos Aguascalientes. Obtenido de Gobierno del Estado de Aguascalientes: https://www.aguascalientes.gob.mx/cplap/Docs /datos/DATOS.pdf

De la Cerda Lémus, M. E. (2011). La familia Burseraceae en el estado de Aguascalientes, México. Acta botánica mexicana, 1-25.

Ghani, S., Bakochristou, F., Mohamed, E., ElBialy, A. A., Mahmoud, S., Gamaledin, A., . . - Ismail, S. M. (2019). Design challenges of agricultural greenhouses in hot and arid environments - A review. Engineering in Agriculture, Environment and Food, 48-70.

Iddio, E., Wang, L., Thomas, Y., McMorrow, G., \& Denzer, A. (2020). Energy efficient operation and modeling for greenhouses: A literature review. Renewable and Sustainable Energy Reviews, 109480.

Rodríguez Penín, A. (2013). Sistemas SCADA. México D.F.: Alfaomega Grupo Editor.

Shamshiri, R. R., Jones, J. W., Thorp, K., Ahmad, D., Che Man, H., \& Taheri, S. (2018). Review of optimum temperature, humidity, and vapour pressure deficit for microclimate evaluation and control in greenhouse cultivation of tomato: A review. International Agrophysics, 287-302.

SIAP, S. d. (2014). Cultivos de agricultura protegida 2014. Obtenido de Datos Abiertos: http://infosiap.siap.gob.mx/gobmx/datosAbierto s.php

SIAP, S. d. (2015). Superficie cubierta y número de instalaciones de agricultura protegida (2015). Obtenido de Datos Abiertos: http://infosiap.siap.gob.mx/gobmx/datosAbierto s.php 